\title{
Structure and Composition of Macroinvertebrates during Flood Period of the Nokoue Lake, Benin
}

\author{
Hamed Odountan*, Youssouf Abou \\ Laboratory of Ecology and Aquatic Ecosystem Management, Department of Zoology, Faculty of Sciences and \\ Technics, University of Abomey-Calavi, Abomey-Calavi, Republic of Benin \\ Email: *oolahamo@gmail.com
}

Received 18 December 2015; accepted 22 January 2016; published 25 January 2016

Copyright @ 2016 by authors and Scientific Research Publishing Inc.

This work is licensed under the Creative Commons Attribution International License (CC BY). http://creativecommons.org/licenses/by/4.0/

(c) (i) Open Access

\section{Abstract}

The Nokoue Lake is the largest lake of Benin Republic and it is also considered as one of the most productive lagoon ecosystems in West Africa. This productivity is decreasing and thus raises productivity issue for a better management and conservation. Macroinvertebrate can be useful for this purpose. A study was conducted to assess the spatial variation of macroinvertebrates during high flood period. A total of 3892 macroinvertebrates of fresh and brackish water were sampled during the survey. Structural analysis of the macroinvertebrate community revealed that it was made up of 16 orders, 48 families and 66 genera dominated by Insecta compared to Mollusca, Crustacea and the Annelida. Insects were dominated by Diptera (Chironomus sp. and Tanytarsus sp.), Coleoptera (Dystiscidae) and accounted for $\mathbf{5 7 . 1 \%}$ of the sampled population. Mollusca, Crustacea, Annelida and Arachnida were the following most abundant and represented $23.9 \%, 10.7 \%, 8.1 \%$ and $0.2 \%$ of the total population, respectively. The Evenness index of Pielou was higher on the Station 8 (0.91 - 0.97), close to Oueme River. However, no significant difference $(p>0.05)$ was observed neither between station nor between month on the Shannon-Wiener index (2.06 - 4.31), Simpson index (0.04 - 0.40) and the taxa number (10 - 27). Macroinvertebrate assemblages and composition were primarily due to changes in water quality dependent on hydroclimatic changes and probably to anthropogenic actions. This suggests the need for real investigation of the macroinvertebrate biological capacity when formulating conservation strategies for the Nokoue Lake.

\section{Keywords}

Nokoue Lake, Macroinvertebrate Community, Structure, Flood Period, Dominant Taxa

\footnotetext{
*Corresponding author.
} 


\section{Introduction}

Water is a natural resource essential for life in any ecosystem and must be of good quality because of the many services it offers (habitat for wildlife and human applications...). The development of human society since the late 19th century led to high levels of pollution in aquatic ecosystems due to agricultural, urban and industrial discharges [1]-[3] which in turn affected the quality of surface waters. These discharges affect the lives of aquatic biota [4]-[6]. Faced to these pollution issues, there is a need to protect aquatic ecosystems and consequently the necessity to monitor the effects of anthropogenic pressure on aquatic ecosystems [7]. Physical and chemical measurements were for many years the most used means for monitoring the quality of the aquatic environment. However, they do not measure the impact of contaminants on biota [8]. Biological methods appear to be an alternative to chemical detection and therefore complement the other methods. The biological approach uses living organisms and has the advantage of being simple and easy to implement. Macroinvertebrates are the most commonly used organisms as aquatic bio-indicators of ecological disturbance because of their ecology, their well-known life history [9]-[11] and easiness of sampling. Macroinvertebrate communities are fundamental to the functioning of aquatic ecosystems due to their importance in organic matter recycling and as essential source of natural food for fisheries [12].

Despite their roles and their importance above mentioned, there are few studies on the macroinvertebrate communities of Benin ecosystems. Indeed, previous works on macroinvertebrate ecology were mainly carried out by [13]-[17]. Concerning the Nokoue Lake (Ramsar site 1018) the largest Benin continental lake, in terms of its extent, productivity and exploitation which ecological integrity is threatened, only the works of [13] [14] exist. These studies did not address the specificity of flood period structure and composition. Although previous studies have been conducted on this ecosystem, related knowledge of macroinvertebrate are then still fragmentary and need to be update.

Knowledge of aquatic biodiversity of lakes like the Nokoue, in particular of macroinvertebrates through seasonal inventory is useful and important, especially as species distribution is heterogeneous in space and time. This study aimed at providing information on the community structure, diversity and seasonal variation of macroinvertebrates in Nokoue Lake. It will serve as complement for future monitoring of the biodiversity of the lake which might suffer biodiversity loss as an issue of proximity of built up human areas and its role as ultimate natural receptor of the Oueme River, the most important Benin River.

\section{Materials and Methods}

\subsection{Study Area}

This study was conducted on Nokoue Lake, located in South Eastern Benin $\left(6^{\circ} 25^{\prime} \mathrm{N}, 2^{\circ} 36^{\prime} \mathrm{E}\right)$ with an area of approximately $150 \mathrm{~km}^{2}$ during the dry period. According to [18] it is the largest brackish water area of Benin. It is shallow with a mean depth of $1.5 \mathrm{~m}$ and has an average length of $20 \mathrm{~km}$ (east-west) and a width of $11 \mathrm{~km}$ (north-south). Oueme River, Sô River and Atlantic Ocean are the main ecosystems which flow into the lake. Furthermore, it communicates in the east with another important ecosystem of south Benin, the Porto-Novo lagoon (35 km² area). The local climate is sub-equatorial climate i.e. an alternation of two rainy seasons and two dry seasons of unequal durations. It follows a water regime characterized by low flood situation May-June, high flood regime September-November and a dry period December-March). Agriculture, trade, fishing, dumping of industrial and municipal wastes and dredging of sand from the lagoon are the main anthropogenic activities affecting the functioning of the lake. The west and the center areas have a muddy bottom while coastal areas of south and east are sandy [19]. Periodically flood plants exists on water surface, and are dominated by the water hyacinth (Eichhornia crassipes) [14] [18] [20] [21].

This study was undertaken in eight stations each consisting of 3 sub-stations (Figure 1) based on previous studies of physical and chemical characteristics of lake water [14] [21] [22]. Stations 1, 2, 3 and 4 have intermediate salinity. Station 1 was located at the touristic village of Ganvie where population is dense. Station 2 was located near the River Sô whereas Station 3 was a very disturbed site because of anthropogenic actions (dredging). Stations 4 and 6 were located at the middle but the latter has high salinity and take place at the lake-channel interface. Stations 5 and 7 have high salinity but the former was located near the outlet of wastewater and storm water of Cotonou city while the latter is characterized by little open station, near the Atlantic Ocean and high salinity, dredged and very disturbed. Station 8 represents a reference situation with which possible comparison can be made. It was at the western and communicates with Porto-Novo lagoon and Oueme River, a tributary of the lake. 


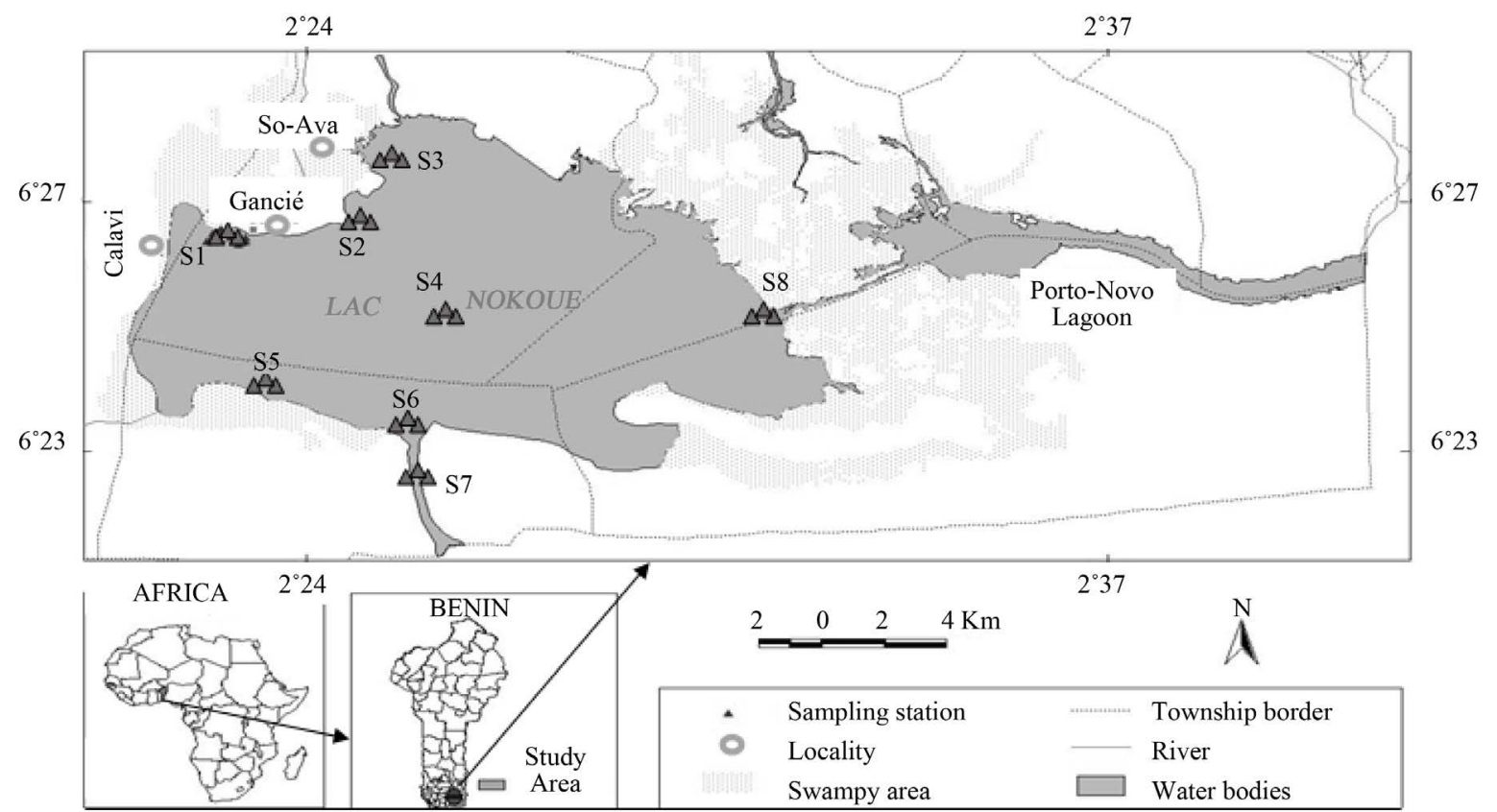

Figure 1. Overview of the study area. The Nokoue Lake ecosystem showing the location of sampling stations caption).

\subsection{Sampling and Analyses}

Samples were collected in September, October and November 2014 during the high flood period at each of the sub-station of the eight sampling stations. A range of physical and chemical water parameters namely the transparency and the depth (determined with a Secchi disk); salinity, conductivity, temperature, Total Dissolved Solids (TDS) (determined using multiparameter digital meter WTW Cond 3210 SET 1); pH (taken with WTW pH multiparameter digital meter 3110 SET 1) and dissolved oxygen (assessed with YSI field Oxi meter Model 550) were measured in situ.

A kick net (mesh size $0.5 \mathrm{~mm}$ ) with a $25 \mathrm{~cm}$ diameter opening, mounted on a steel shaft of $3 \mathrm{~m}$ was used along a transect of $3 \mathrm{~m}$ to sample. In addition, samples of 8 root system of Eichhornia crassipes per substations were also made because of its abundance in quiet areas and the density of its root system which can be a favorable habitat for macroinvertebrates [23] [24].

Samples obtained were carefully washed through a set of sieves of mesh size $0.2 \mathrm{~mm}$ in the water of the lake and the retained materiel was bottled and preserved in $5 \%$ formalin. In the laboratory, the samples were washed again through a set of sieves of mesh sizes $0.2 \mathrm{~mm}, 0.5 \mathrm{~mm}, 1 \mathrm{~mm}$ and $2 \mathrm{~mm}$. Organisms were then separated according to their order or class and preserved with $70 \%$ absolute ethanol for identification. Macroinvertebrates were identified with binocular dissecting microscope (Jeulin, Model 02010) to the lowest practicable and possible taxonomic level, mostly genus, according to [12] [25]-[31], and consulting specialists.

The macroinvertebrate assemblage composition was evaluated for each sampling station and sampling occasion using number of taxa (S), total number of individuals, and relative abundance of each taxon. The calculated parameters were used to assess the well-being/ health of the habitats. The diversity of macroinvertebrates was assessed using the Shannon-Wiener diversity index $\left(H^{\prime}\right)$ as described by [32] with the following formula:

$$
H^{\prime}=-\sum\left(p_{i} \times \log _{2} p_{i}\right) .
$$

where $p_{i}=$ number of individuals of the taxon/total number of individuals of the sample and $\log _{2}=$ the 2 base logarithm. The Evenness index $(E)$ [33] was calculated to compare the differences of two stations with different species as follows:

$$
E=H^{\prime} / \log _{2} S
$$

where $H^{\prime}$ is the Shannon-Wiener diversity index and $S$ the total number of taxa. The Simpson index $\left(D_{s}\right)$ [34] 
allowed knowing the taxonomic richness of the medium [35]. It was calculated with the following formula:

$$
D_{s}=\sum n_{i}\left(n_{i}-1\right) / N(N-1) .
$$

With $n_{i}=$ the number of species in the sample and $N$ is the total number of individuals.

\subsection{Statistical Analysis}

Physicochemical parameters were expressed as means \pm Standard Deviation for each station. Before performing the comparison test, the normality of data was checked by the Ryan-Joiner test using Minitab (16 Fr) software. Kruskal-wallis's test was performed to determine any significant differences between stations for each parameter at the significance level of 5\%. Man-Whitney's test was done in order to separate the stations that differed significantly from one another. Community indices listed above were used to compare dominance, richness, diversity, and evenness of macroinvertebrates between stations. Data analysis was done using Statistical Package for Social Sciences (IBM SPSS Statistics version 20).

\section{Results}

\subsection{Environmental Variables}

The summary of means values obtained per station for environmental variables is presented in Table 1. Environmental variables such as transparency, depth, temperature, $\mathrm{pH}$, salinity, conductivity and TDS exhibit all significant difference between the sampling stations, while no significant difference was observed for dissolved oxygen. Analysis showed three homogeneous groups for depth with the Station 8 having the highest mean value. The same station has the lowest temperature value $\left(28.52^{\circ} \mathrm{C}\right)$. Station 5 has the lowest transparency value $(0.29 \mathrm{~m})$ while Station 1 has the highest $(0.62 \mathrm{~m})$. The $\mathrm{pH}$ varied from 6.5 (Stations 2 and 3) to 7.8 (Station 7). In this study, salinity, conductivity and TDS tests conducted showed two distinct groups with the same trend. Stations 5, 6 and 7 have higher values while Stations 1, 2, 3, 4 and 8 have lower values; for those three variables, Station 8 has the lowest value while Station 7 has the highest. Salinity fluctuated between $0 \%$ and $2.03 \%$ while conductivity varied from $87.9 \mu \mathrm{S} \cdot \mathrm{cm}^{-1}$ to $3685 \mu \mathrm{S} \cdot \mathrm{cm}^{-1}$.

\subsection{Macroinvertebrate Taxonomic Composition}

The macroinvertebrate taxa found in Nokoue Lake are presented in Table 2 and the relative abundances of different groups in general and per station are presented in Figure 2 and Figure 3. A total of 3892 macroinvertebrate specimens were collected during the survey. These organisms belong to three (03) phyla (Arthropoda,

Table 1. Spatial variation of the physicochemical parameters measured during 2014 high flood in nokoue lake.

\begin{tabular}{|c|c|c|c|c|c|c|c|c|}
\hline \multirow{2}{*}{ Variable } & \multicolumn{8}{|c|}{ Station } \\
\hline & S1 & S2 & S3 & S4 & S5 & S6 & S7 & S8 \\
\hline Depth (m) & $1.71^{\mathrm{b}} \pm 0.48$ & $1.58^{\mathrm{b}} \pm 0.36$ & $1.05^{\mathrm{a}} \pm 0.24$ & $1.11^{\mathrm{a}} \pm 0.18$ & $0.94^{\mathrm{a}} \pm 0.33$ & $1.49^{\mathrm{b}} \pm 0.37$ & $1.71^{\mathrm{b}} \pm 0.46$ & $2.12^{\mathrm{c}} \pm 0.27$ \\
\hline $\begin{array}{l}\text { Temperature } \\
\left({ }^{\circ} \mathrm{C}\right)\end{array}$ & $29.2^{\mathrm{ab}} \pm 0.9$ & $30.26^{\mathrm{bc}} \pm 0.8$ & $30.8^{\mathrm{c}} \pm 0.8$ & $30.2^{\mathrm{bc}} \pm 1.28$ & $29.9^{\mathrm{abc}} \pm 1.2$ & $28.9^{\mathrm{ab}} \pm 1.07$ & $28.9^{\mathrm{ab}} \pm 0.95$ & $28.5^{\mathrm{a}} \pm 1.23$ \\
\hline $\begin{array}{l}\text { Transparency } \\
\text { (m) }\end{array}$ & $0.62^{\mathrm{b}} \pm 0.29$ & $0.54^{\mathrm{ab}} \pm 0.36$ & $0.4^{\mathrm{ab}} \pm 0.16$ & $0.47^{\mathrm{ab}} \pm 0.26$ & $0.29^{\mathrm{a}} \pm 0.09$ & $0.43^{\mathrm{ab}} \pm 0.11$ & $0.43^{\mathrm{ab}} \pm 0.11$ & $0.33^{\mathrm{ab}} \pm 0.06$ \\
\hline $\begin{array}{l}\text { Dissolved } \\
\text { oxygen } \\
\left(\mathrm{mg} \cdot \mathrm{L}^{-1}\right)\end{array}$ & $2.16^{\mathrm{a}} \pm 1.09$ & $2.85^{\mathrm{a}} \pm 1.46$ & $2.76^{\mathrm{a}} \pm 1.33$ & $2.66^{\mathrm{a}} \pm 1.59$ & $2.58^{\mathrm{a}} \pm 1.38$ & $3.36^{\mathrm{a}} \pm 1.9$ & $3.47^{\mathrm{a}} \pm 1.9$ & $2.65^{\mathrm{a}} \pm 1.38$ \\
\hline $\mathrm{pH}$ & $6.6^{\mathrm{a}} \pm 0.5$ & $6.5^{\mathrm{a}} \pm 0.4$ & $6.5^{\mathrm{a}} \pm 0.6$ & $6.6^{\mathrm{a}} \pm 0.5$ & $7.2^{\mathrm{bc}} \pm 0.3$ & $7.5^{\mathrm{cd}} \pm 0.6$ & $7.8^{\mathrm{d}} \pm 0.2$ & $6.9^{\mathrm{ab}} \pm 0.3$ \\
\hline $\begin{array}{l}\text { Salinity } \\
(\%)\end{array}$ & $0.01^{\mathrm{a}} \pm 0.03$ & $0.02^{\mathrm{a}} \pm 0.07$ & $0.01^{\mathrm{a}} \pm 0.03$ & $0.03^{\mathrm{a}} \pm 0.1$ & $1.94^{\mathrm{b}} \pm 1.90$ & $1.42^{\mathrm{b}} \pm 1.67$ & $2.03^{\mathrm{b}} \pm 2.52$ & $0^{\mathrm{a}} \pm 0$ \\
\hline $\begin{array}{l}\text { Conductivity } \\
\left(\mu \mathrm{S} \cdot \mathrm{cm}^{-1}\right)\end{array}$ & $165.5^{\mathrm{a}} \pm 115.2$ & $152.9^{\mathrm{a}} \pm 30.8$ & $152.3^{\mathrm{a}} \pm 97.7$ & $155.9^{\mathrm{a}} \pm 89.8$ & $3569^{\mathrm{b}} \pm 3317$ & $3474^{\mathrm{b}} \pm 4686$ & $3685^{\mathrm{b}} \pm 4332$ & $87.9^{\mathrm{a}} \pm 15.5$ \\
\hline $\begin{array}{c}\text { TDS } \\
\left(\mathrm{mg} \cdot \mathrm{L}^{-1}\right)\end{array}$ & $165.3^{\mathrm{a}} \pm 115.1$ & $152.4^{\mathrm{a}} \pm 129.2$ & $152.9^{\mathrm{a}} \pm 98.5$ & $156.3^{\mathrm{a}} \pm 90.3$ & $3576^{\mathrm{b}} \pm 3328$ & $3467^{\mathrm{b}} \pm 4691$ & $3656^{\mathrm{b}} \pm 4234$ & $87.9^{\mathrm{a}} \pm 15.5$ \\
\hline
\end{tabular}

${ }^{a, b, c}$ In each line, means with the same letters as superscripts are not significantly different $(\mathrm{p}>0.05)$. 
Table 2. Composition, distribution and taxon richness of macroinvertebrates during 2014 high flood in Nokoue Lake. -: absent. + : present $(0<$ individuals $\leq 10)$. ++ : plenty $(10<$ individuals $\leq 100)$. +++ : very plenty (individuals $>100)$.

\begin{tabular}{|c|c|c|c|c|c|c|c|c|c|c|c|c|}
\hline \multirow{2}{*}{ Phylum } & \multirow{2}{*}{ Class } & \multirow{2}{*}{ Order } & \multirow{2}{*}{ Family } & \multirow{2}{*}{ Genus \& species } & \multicolumn{8}{|c|}{ Station } \\
\hline & & & & & S1 & S2 & S3 & S4 & S5 & S6 & & S8 \\
\hline \multirow[t]{37}{*}{ ARTHROPODA } & Insecta & Odonata & Libellulidae & Orthetrum sp. & + & - & - & - & - & - & - & - \\
\hline & & & & Libellula sp. & - & + & + & + & + & - & - & + \\
\hline & & & Lestidae & Lestes sp. & + & - & + & - & - & - & - & + \\
\hline & & & Coenagrionidae & Ischnura sp. & + & + & + & - & - & - & - & - \\
\hline & & & & Coenagrion sp. & + & + & ++ & + & + & - & + & + \\
\hline & & & & Enallagma sp. & - & + & - & - & - & - & - & - \\
\hline & & & Aeshnidae & Aeshna sp. & - & - & - & + & + & - & - & - \\
\hline & & & Calopterygidae & Calopteryx sp. & - & - & - & - & - & - & - & + \\
\hline & & & Corduliidae & Cordulia sp. & - & - & - & - & - & - & - & + \\
\hline & & Ephemeroptera & Caenidae & Brachycercus sp. & + & - & - & - & - & - & - & - \\
\hline & & & & Caenis sp. & + & - & + & + & + & - & + & ++ \\
\hline & & & & Caenodes sp. & - & - & - & - & - & - & - & + \\
\hline & & & Baetidae & Baetis sp. & + & + & + & ++ & - & - & + & ++ \\
\hline & & & & Procloeon sp. & - & - & - & - & - & - & - & + \\
\hline & & & & Cloeon sp. & - & - & - & - & - & - & + & + \\
\hline & & & Heptagenidae & Afronerus sp. & - & - & - & - & - & - & - & + \\
\hline & & & Leptophlebiidae & & - & - & - & - & - & - & - & + \\
\hline & & Diptera & Chironomidae & Chironomus sp. & +++ & +++ & +++ & +++ & +++ & ++ & + & ++ \\
\hline & & & & Tanytarcus sp. & ++ & ++ & ++ & +++ & ++ & ++ & + & ++ \\
\hline & & & & Polypedilum sp. & ++ & ++ & ++ & ++ & - & - & - & + \\
\hline & & & Culicidae & Culex sp. & + & + & + & - & + & - & - & + \\
\hline & & & Dixidae & Dixa sp. & - & - & - & - & - & - & - & + \\
\hline & & & Ceratoporinidae & & - & + & - & - & - & - & - & - \\
\hline & & & Tabanidae & & - & - & - & - & - & + & - & - \\
\hline & & Coleoptera & Dystiscidae & Hyphydrus sp. & ++ & ++ & + & + & + & - & - & + \\
\hline & & & & Dytiscus sp. & ++ & ++ & ++ & + & + & - & + & + \\
\hline & & & & Hydrovatus sp. & + & - & + & - & - & - & - & - \\
\hline & & & & Canthydrus sp. & - & - & - & + & + & - & - & - \\
\hline & & & & Meladema sp. & - & - & - & - & - & - & - & + \\
\hline & & & Dryopidae & Dryops sp. & - & - & + & - & - & - & - & - \\
\hline & & & Haliplidae & Haliplus sp. & + & + & + & + & - & - & + & + \\
\hline & & & Hydraenidae & & - & + & - & - & - & - & - & + \\
\hline & & & Hydrophilidae & Amphiops sp. & - & - & + & - & - & - & - & + \\
\hline & & & & Hydrophilus sp. & - & - & + & - & - & - & - & + \\
\hline & & Heteroptera & Notonectidae & Paraplea sp. & + & + & + & + & - & - & - & + \\
\hline & & & Naucoridae & Macrocoris sp. & - & + & + & + & - & - & - & + \\
\hline & & & & Ilyocoris sp. & - & + & - & - & - & - & - & - \\
\hline
\end{tabular}




\section{Continued}

\begin{tabular}{|c|c|c|c|c|c|c|c|c|c|c|c|c|}
\hline & & & Corixidae & Micronecta sp. & - & + & ++ & - & - & - & - & - \\
\hline & & & Nepidae & Ranatravicina & - & - & - & - & - & - & - & + \\
\hline & & & Belostomatidae & Apassus sp. & - & - & + & - & - & - & - & - \\
\hline & & & & undetermined & - & - & - & - & - & - & - & + \\
\hline & & Lepidoptera & Pyralidae & Elophila sp. & - & + & - & - & - & - & + & + \\
\hline & & Collembola & Isotomidae & Isotomurus sp. & - & - & - & - & - & - & + & - \\
\hline & Malacostraca & Amphipoda & Amphilochidae & Amphilocus sp. & + & + & + & + & - & + & + & - \\
\hline & & & Aoridae & Grandidierella sp. & + & + & - & + & - & + & ++ & - \\
\hline & & & Photidae & Photis sp. & + & - & + & + & - & - & + & - \\
\hline & & & Gammaridae & Gammarus sp. & + & + & + & + & + & + & - & + \\
\hline & & Isopoda & Cirolanidae & Excirolana sp. & - & - & - & + & + & + & - & - \\
\hline & & & Sphaeromatidae & Sphaeroma sp. & - & + & - & + & - & + & - & - \\
\hline & & Decapoda & Grapsidae & Goniopsis Cruentata & - & + & + & + & ++ & ++ & ++ & - \\
\hline & & & & Pachygrapsus sp. & - & - & - & - & + & + & ++ & - \\
\hline & & & Portunidae & Callinectespalitus & + & + & + & + & ++ & ++ & ++ & - \\
\hline & & & & Callinectesamnicola & + & + & + & + & ++ & + & ++ & - \\
\hline & & & Peneaeidae & Penaeus sp. & - & - & - & - & ++ & + & ++ & - \\
\hline & Arachnida & & Pisauridae & Dolomedes sp. & + & - & + & - & - & - & - & + \\
\hline & & & & Undetermined & - & - & - & - & + & - & - & - \\
\hline & & & Undetermined & & - & + & - & - & - & - & - & - \\
\hline MOLLUSCA & Gastropoda & & & Thympanotonus fuscatus & ++ & ++ & ++ & ++ & ++ & ++ & ++ & ++ \\
\hline & & & Potamididae & Turitella sp. & + & + & - & + & + & + & + & - \\
\hline & & & & Cancellaria sp. & - & - & - & - & - & + & + & - \\
\hline & & & & Pachymelania sp. & + & + & + & - & + & ++ & ++ & - \\
\hline & & & Planorbidae & Gyraulus sp. & + & + & ++ & + & - & - & - & ++ \\
\hline & & & Bithynidae & Gabbiella sp. & + & + & + & ++ & - & + & + & ++ \\
\hline & Bivalvia & & Ostreidae & Crassostrea sp. & - & - & - & - & + & ++ & ++ & - \\
\hline & & & Corbulidae & Corbula sp. & + & + & ++ & + & + & ++ & ++ & ++ \\
\hline & & & Mytilidae & Brachiodontes sp. & - & - & + & - & + & + & ++ & + \\
\hline & & & Dreissenidae & Dreissenaafricana & - & - & - & - & - & + & + & - \\
\hline ANNELIDA & Oligochaeta & & Tubificidae & Branchiura sp. & + & ++ & ++ & ++ & + & - & ++ & + \\
\hline & & & Naididae & Branchiodrilus sp. & - & - & + & + & + & + & ++ & + \\
\hline & Polychaeta & & Nereidae & Nereis sp. & - & + & + & + & - & +++ & ++ & + \\
\hline & & & Serpulidae & Serpula sp. & - & + & - & - & + & + & ++ & - \\
\hline \multicolumn{5}{|c|}{ Taxonomic diversity (genera) } & 29 & 35 & 36 & 30 & 26 & 24 & 30 & 39 \\
\hline \multicolumn{5}{|c|}{ Individual number } & 508 & 400 & 603 & 980 & 362 & 310 & 482 & 247 \\
\hline
\end{tabular}

Annelida and Mollusca) divided into 16 orders, 48 families and 66 genera. Arthropoda were the most abundant and diversified phylum with 37 families (78\% of individuals), while Mollusca and Annelida contain respectively 07 families (23.9\% of individuals) and 04 families (8.1\% of individuals). Insects were the most abundant (57.1\%) of Arthropoda with high number of Chironomidae (47\%), while Gastropoda (17.4\%) especially Thympanotonus 


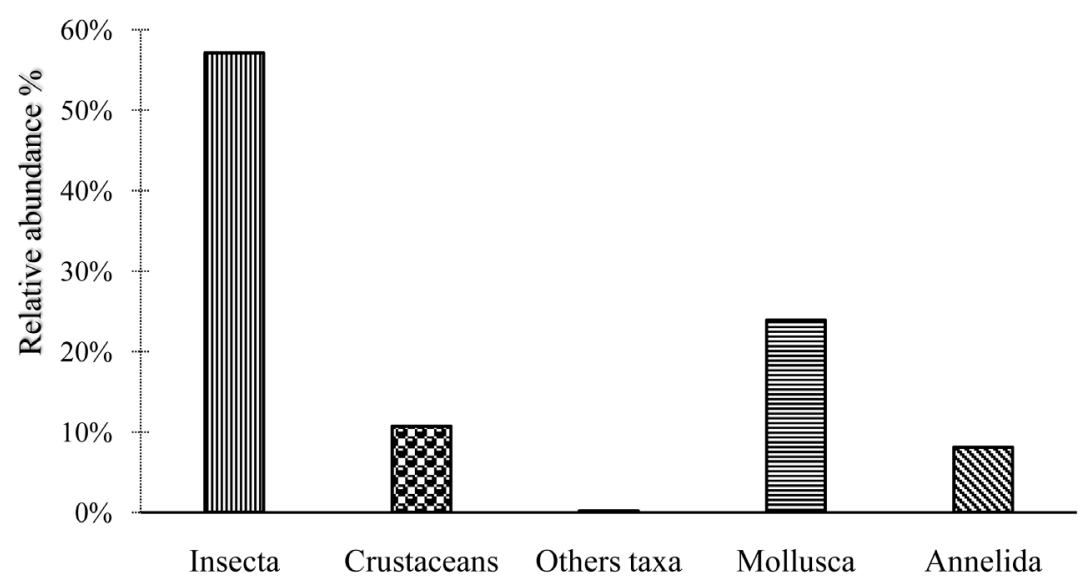

Figure 2. Relative abundance of macroinvertebrate during high flood in nokoue lake.

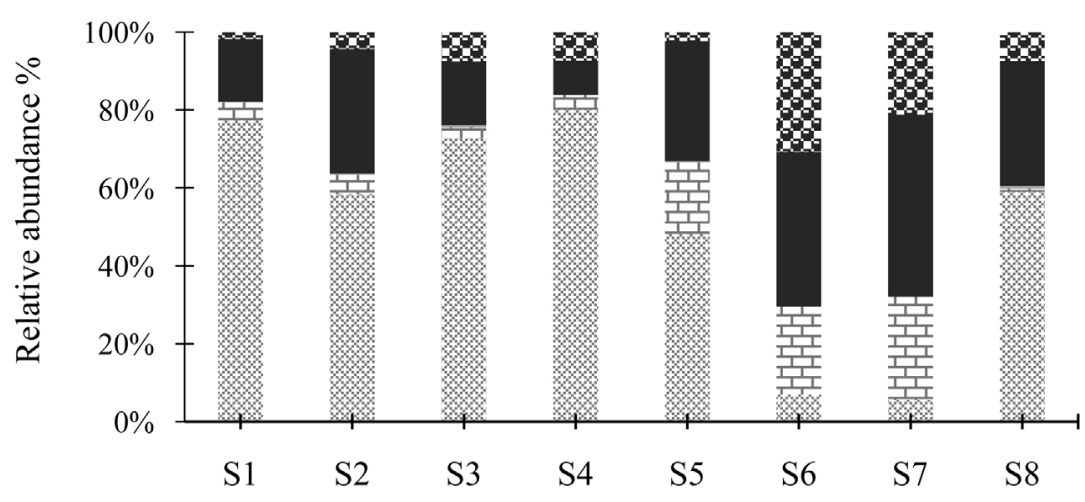

$$
\text { Insecta 고 Crustaceans } \square \text { Others taxa } \square \text { Mollusca Annelida }
$$

Figure 3. Relative abundance of different groups at the sampling stations during high flood in nokoue lake.

sp. are responsible for the Mollusca abundance. Station 8 had the highest taxa richness with 39 genera (240 individuals), followed in this order by Station 3 with 36 genera (603 individuals), Station 2 with 35 genera (400 individuals), Stations 4 and 7 each with 35 genera, 980 and 482 individuals respectively, Station 1 with 29 genera (508 individuals), Station 5 with 26 genera (362 individuals) and Station 6 with 24 genera (310 individuals). In addition, some families or genera were found only on particular stations. This was the case of Baetidae (Procloeon sp.), Caenidae (Caenodes sp.), Corduliidae (Cordulia sp.), Calopterygidae (Calopteryx sp.), Heptagenidae (Afronerus sp.), Dixidae (Dixa sp.), Dystiscidae (Meladema sp.) and Leptophlebiidae collected only at Station 8. Caenidae (Brachycercus sp.) and Libellulidae (Orthetrum sp.) were collected only at Station 1. Coenagrionidae (Enallagma sp.), Ceratoporinidae, Naucoridae (Ilyocoris sp.) only at Station 2; Driopidae (Dryops sp.) and Belostomatidae (Apassus sp.) collected only at Station 3 like Tabanidae and Isotomidae collected at Stations 6 and 7, respectively. Insects were most abundant at Station 1 (77\%), Station 2 (58\%), Station 3 (73\%), Station 4 (80\%) and Station 8 (59\%) where the salinity is closed to zero, while Mollusca were most abundant at Stations 6 and 7 with non-zero salinity. There was also a dominance of Annelida at the Stations 6 and 7 related to the abundance of Polychaeta while for other stations, Annelida are mainly represented by the Oligochaeta.

Table 3 shows the monthly distribution of taxa (genera) by stations and some diversity indices giving insight on the structure of the collected macroinvertebrates.

The taxon richness is on average 18 in November and 20 in September. However, there is no significant difference of taxon richness neither between months nor between stations $(\mathrm{p}>0.05)$. During September, diversity was between 3.16 (Station 1) and 4.17 (Station 3) while the Simpson index was between 0.07 (Stations 7 and 8) 
Table 3. Taxon richness and macroinvertebrate diversity indices in Nokoue Lake ecosystem during high flood period. $\mathrm{N}=$ Number of generic taxon. $H^{\prime}=$ Shannon-Wiener diversity. E = Evenness index. Ds = Simpson index.

\begin{tabular}{|c|c|c|c|c|c|c|c|c|}
\hline \multirow{2}{*}{ Variable } & \multicolumn{8}{|c|}{ Station } \\
\hline & $\mathrm{S} 1$ & S2 & S3 & $\mathrm{S} 4$ & S5 & S6 & S7 & S8 \\
\hline N-taxon ${ }_{\text {September }}$ & 19 & 21 & 28 & 27 & 14 & 16 & 20 & 15 \\
\hline N-taxon ${ }_{\text {October }}$ & 17 & 20 & 19 & 14 & 10 & 20 & 26 & 22 \\
\hline N-taxon November & 15 & 19 & 17 & 17 & 16 & 13 & 20 & 27 \\
\hline H'September & 3.19 & 3.77 & 4.17 & 4.04 & 3.16 & 3.47 & 3.95 & 3.74 \\
\hline $\mathrm{H}^{\prime}$ October & 2.83 & 3.31 & 2.34 & 2.11 & 2.06 & 3.20 & 3.92 & 4.35 \\
\hline $\mathrm{H}^{\prime}$ November & 2.42 & 3.36 & 3.05 & 2.22 & 2.97 & 3.31 & 3.66 & 4.33 \\
\hline $\mathrm{E}_{\text {September }}$ & 0.75 & 0.86 & 0.87 & 0.86 & 0.83 & 0.87 & 0.91 & 3.74 \\
\hline $\mathrm{E}_{\text {October }}$ & 0.69 & 0.77 & 0.55 & 0.55 & 0.62 & 0.74 & 0.83 & 4.35 \\
\hline $\mathrm{E}_{\text {November }}$ & 0.62 & 0.79 & 0.75 & 0.54 & 0.74 & 0.89 & 0.85 & 4.33 \\
\hline Ds ${ }_{\text {September }}$ & 0.19 & 0.09 & 0.08 & 0.08 & 0.13 & 0.11 & 0.07 & 0.07 \\
\hline Ds October & 0.23 & 0.17 & 0.32 & 0.32 & 0.34 & 0.19 & 0.10 & 0.04 \\
\hline $\mathrm{Ds}_{\text {November }}$ & 0.33 & 0.14 & 0.20 & 0.40 & 0.18 & 0.11 & 0.10 & 0.06 \\
\hline
\end{tabular}

and 0.19 (Station 1). In October the diversity had varied between 2.06 (Station 1) and 4.35 (Station 8) while the Simpson index was between 0.04 (Station 8) and 0.34 (Station 1). On the other hand in November, diversity was lower at Station 4 (2.22) but still higher at Station 8 (4.33) where the Simpson index was still lower (0.04) compared to other stations but higher in October at the Station $4(0.40)$. The equitability index regardless of the month was above 0.5 and generally at all stations, it had the highest value in September. Consistency was remarkable at Station 8 (0.91 to 0.97) compared to other stations during all three months. Finally, the analysis of variance without considering simultaneously the two factors (the month and the station) revealed that there is no significant difference ( $p>0.05$ ) in the three indices across the three months contrary to the equitability index that varies across stations $(p=0.043)$ although the Shannon diversity and Simpson indices were constant across stations.

\section{Discussion}

\subsection{Water Quality Status of Nokoue Lake}

The results indicate spatial variation of the water physicochemical parameters of Nokoue Lake during the study period. The physicochemical parameters allow us to know the evolution of the water quality of an ecosystem from upstream to downstream [36] [37]. The depth value deviates from the average value of $1.5 \mathrm{~m}$ reported by [38] especially at the Station 8 where unregulated dredging sand of the lagoon is accentuated. Temperature values were high and remain similar to those of previous studies conducted by [22] [39] in the same period. Dissolved oxygen values are lower than those obtained in Tanganyika Lake $\left(6.64 \mathrm{mg} \cdot \mathrm{L}^{-1}\right)$ by [40] and increase at the stations close to the sea and station 5, as also reported by [14]. The $\mathrm{pH}$ averages were consistent with the results of [14] [38] [39] who found a $\mathrm{pH}$ between 6.3 and 7.8. The salinity of the Nokoue Lake varies but its attributes were typical of brackish water, similar to [14] [22] [38] [39] findings. The difference obtained between stations can be explained by several factors. Dilution (freshwater inputs from tributaries and direct precipitation) decreases the salinity while tides (saltwater intrusion) via Cotonou channel increase it [22] [38] [39]. These same factors have also been identified as causes of salinity fluctuations in Aheme Lake [41] Epe lagoon [42] and the intertidal zone of the Niger Delta [43]. Conductivity indicates the ability of water to conduct the electricity. It allows assessing very quickly and with approximation the overall mineral content of the water. The proximity of the ocean, high tides, freshwater inflows and salinity are the most important factors determining the conductivity which move in the same direction as the salinity [39] [41] [43] [44]. Even if the values differ, the TDS illustrates a trend similar to that of salinity and conductivity. This view and Simpson indices were constant across stations [16] [36] [37] [45] who demonstrated that there is a strong dependence between temperature, the parameters related to the mineralization ( $\mathrm{pH}$ and conductivity, TDS), the organic load, salinity, transparency and current velocity. 


\subsection{Macroinvertebrates}

The main groups of organisms listed in the study were mostly aquatic insects larvae (Diptera, Coleoptera, Ephemeroptera, Heteroptera, Odonata, and rarely Lepidoptera and Collembola), Mollusca (Bivalvia and Gastropoda), Crustacea (Isopoda, Amphipoda and Decapoda) and Annelida (Oligochaeta and Polychaeta). These various listed macroinvertebrate groups are not in contrast with those reported by previous studies in other lagoon ecosystems in southern Benin, Nigeria and Ivory Coast [14] [15] [17] [42] [46] [47]. However, differences remain either in the taxa number or the dominant group between these results and those of the current study. This could be explained by the difference between the scope settings, the sampling period, and environments nature. Indeed, Aby lagoon in Ivory Coast is larger $\left(424 \mathrm{~km}^{2}\right)$ while the coastal lagoon in Benin and Epe Lagoon in Nigeria are less extensive with $52 \mathrm{~km}^{2}$ and $225 \mathrm{~km}^{2}$, respectively. But they share a coastal extent or greater salinity than that characterizing the Nokoue Lake [15] [42] [47]. This therefore justifies the dominance of brackish water zoological groups such as Mollusca, Crustaceans and Annelida (Polychaeta). In ecosystems such as Ologe lagoon and the Porto-Novo lagoon, the insects were noted as dominant but in different proportions or order. That disparity could be explained by the nature of the habitat, the sampling frequency, the duration of the study, the collection method and the scope of the study as mentioned by [46] and when comparing our results to those of [17] and [47]. A strict comparison cannot be made with previous results obtained by [14] in two years which includes 76 taxa (orders, families and genera). Chironomidae (Chironomus sp., Tanynarsus sp., and Polypedilium sp.), Potamididae (Tympanotomus sp., Turitella sp., Pachymelania sp., and Cancellaria sp.), Dystiscidae (Dystiscus sp., Hyphydrus sp. Hydrovatus sp., Canthydrus sp. and Meladema sp.) and Grapsidae (Goniopsis cruentata, Pachygrapsus sp.) are in order, the most abundant families during the sampling period. This distribution is generally one at the Stations 1, 2, 3 and 4 while Potamididae, Ostreidae and Polychaeta are most abundant at Stations 5, 6 and 7. Station 5 was more akin to the latter group. These qualitative findings call for special remarks, some related to morphological and biological traits of organisms, other to physical characteristics of the environment. An aquatic ecosystem which constantly changed and renewed habitat is characterized by the depth, current speed and substrate which change over time and space. It follows a dynamic diversity of this ecosystem [48]. This could explain the highest diversity at Station 8 where the depth, the less muddy substrate and other morphological factors favor the presence of species such as Procloeon sp., Caenodes sp., Cordulia sp., Calopteryx sp., Afronerus sp., Dixa sp., and Meladema sp. The very high evenness (0.91 to 0.97) and very low Simpson's diversity (0.04 to 0.07 ) reflect a combination of habitat factors that do not favor the strong dominance of any species. In contrast, decomposition of acadjas branches (muddy areas), the shallow depth and the low use dissoved oxygen value could explain the strong dominance of Chironomidae at Stations 1, 2, 3, 4 and 5 . This is corroborated by the trend of diversity indices.

This study does not inform about the real biodiversity, of the Nokoue Lake, because of its very specific period. It must therefore be thoroughly over an annually period at least. Indeed, spatial and temporal variation in habitat conditions e.g. flow regime affects movements, composition, diversity and assemblages of aquatic macroinvertebrates [49]-[51]. Nevertheless, during the same period of high flood, macroinvertebrate assemblage changes can be used as biological indicator of water quality of the Nokoue Lake [52].

\section{Conclusion}

Findings of this study illustrate that Nokoue Lake is characterized by a spatial and temporal change of physicochemical parameters. These parameters are dependent on periodic hydro-climatic variations in the lake and human activities. The macroinvertebrates structure of Nokoue Lake varies across stations. The species recorded belong to 16 orders, 48 families and 66 genera and are mostly Insecta, mainly Chironomidae. The macroinvertebrate fauna is mainly freshwater during periods of high water but is enriched with brackish water species during times of low water. Station 8 and stations close to the ocean have presented species of fresh and brackish water respectively. This work therefore provides baseline information for management and conservation of Nokoue Lake, especially during high flood period. However, further investigations should be performed during the same period on a real bio-indicator capacity of macroinvertebrate in order to efficiently monitor Nokoue Lake ecosystem.

\section{Acknowledgements}

The authors are most grateful to the Belgian National Focal Point to the Global Taxonomy Initiative, which 
granted to Hamed Odountan Internship travel grant for taxonomy capacity building.

\section{References}

[1] Smolders, R., Bervoets, L., Wepener, V. and Blust, R. (2003) A Conceptual Framework for Using Mussels as Biomonitors in Whole Effluent Toxicity. Human and Ecological Risk Assessment, 9, 741-760. http://dx.doi.org/10.1080/713609965

[2] Rao, J.V., Kavitha, P., Srikanth, K., Usman, P.K. and Rao, T.G. (2007) Environmental Contamination Using Accumulation of Metals in Marine Sponge, Sigmadocia fibulata Inhabiting the Coastal Waters of Gulf of Mannar, India. Toxicological and Environmental Chemestry, 89, 487-498. http://dx.doi.org/10.1080/02772240601150588

[3] d'Adamo R., Di-Stasio M. and Fabbrochini, A. (2008) Migratory Crustaceans as Biomonitors of Metal Pollution in Their Nursery Areas: The Lesina Lagoon Italy as a Case Study. Evironmental Monitoring and Assessment, 143, 15-24. http://dx.doi.org/10.1007/s10661-007-9944-3

[4] Boening, D.W. (1999) An Evaluation of Bivalves as Biomonitors of Heavy Metals Pollution in Marine Waters. Environmental Monitoring and Assessment, 55, 459-470. http://dx.doi.org/10.1023/A:1005995217901

[5] Viaroli, P., Bartoli, M., Giordani, G., Austoni, M. and Zaldivar, J.M. (2005) Biochemical Processes in Coastal Lagoons: From Chemical Reactions to Ecosystem Functions and Properties. Indicators of Stress in the Marine Benthos. IOC Workshop Report No. 195, 27-30.

[6] Warwick, R. (2005) Taxonomic Distinctness as an Indicator of Stress in the Marine Macrobenthos. Indicators of Stress in the Marine Benthos, IOC Workshop Report No. 195, 10-11.

[7] Burger, J. (2006) Bioindicators: A Review of Their Use in the Environmental Literature 1970-2005. Environmental Bioindicators, 1, 136-144. http://dx.doi.org/10.1080/15555270600701540

[8] Belanger, D. (2009) Utilisation de la faune macrobenthique comme bio-indicateur de la qualité de l'environnement côtier. Mémoire de Maitrise, Université de Sherbrooke, Québec, 67 p.

[9] Rosenberg, D.M. and Resh, V.H. (1993) Introduction to Freshwater Biomonitoring and Benthic Macroinvertebrates. In: Rosenberg, D.M., Resh, V.H., Eds., Freshwater Biomonitoring and Benthic Macroinvertebrates, Chapman \& Hall, New York.

[10] Clarke, K.R. and Warwick, R.M. (2001) Changes in Marine Communities: An Approach to Statistical Analysis and Interpretation. 2nd Edition, PRIMER-E: Plymouth Marine Laboratory, UK, 176 p.

[11] Clarke, R.T., Furse, M.T., Gunn, R.J.M., Winder, J.M. and Wright, J.F. (2002) Sampling Variation in Macroinvertebrate Data and Implications for River Quality Indices. Freshwater Biology, 47, 1735-1751. http://dx.doi.org/10.1046/j.1365-2427.2002.00885.x

[12] Tachet, H., Richoux, P., Bourneau, M. and Usseglio-Polatera, P. (2010) Freshwater Invertebrates, Systematics, Biology, Ecology. CNRS Editions, Paris.

[13] Gnohossou, P. (2002) Influence of Organic Pollution on Nokoue Lake Invertebrates. Thorough Agronomy Thesis, National School of Agronomy of Toulouse, France.

[14] Gnohossou, P. (2006) The Benthic Fauna of a West African Lagoon (Nokoue Lake in Benin), Diversity, Abundance Temporal and Spatial Variations, Place in the Food Chain. Ph.D. Thesis, National School of Agronomy of Toulouse, France.

[15] Adandedjan, D., Lalèyè, P. and Gourene, G. (2012) Macroinvertebrates Communities of a Coastal Lagoon in Southern Benin. International Journal of Biological and Chemical Science, 6, 1233-1252.

[16] Adandedjan, D., Montcho, A.S., Chikou, A., Lalèyè, P. and Gourene, G. (2013) Caractérisation des peuplements de macroinvertébrés benthiques à l'aide de la Carte Auto-organisatrice SOM. Comptes Rendus Biologies, 336, $244-248$. http://dx.doi.org/10.1016/j.crvi.2013.04.009

[17] Adandedjan, D., Lalèyè, P., Ouattara, A. and Gourene, G. (2011) Distribution of Benthic Insect Fauna in a West African Lagoon: The Porto-Novo Lagoon in Benin. Asian Journal of Biological Sciences, 4, 116-127. http://dx.doi.org/10.3923/ajbs.2011.116.127

[18] Lalèyè, P., Niyonkuru, C., Moreau, J. and Teugels, G.G. (2003) Spatial and Seasonal Distribution of the Ichthyofauna of Lake Nokoué, Benin, West Africa. African Journal of Aquatic Sciences, 28, 151-161. http://dx.doi.org/10.2989/16085910309503779

[19] Adounvo, D.U. (2001) Etude comparée de la productivité primaire des lacs Nokoué et Ahémé au Bénin. Thèse d’ingénieur Agronome, Université Nationale du Benin, Bénin.

[20] Niyonkuru, C. (2001) Les variations temporelles de la faune ichtyologique du lac Nokoué. Mémoire de DESS, Université Abomey Calavi, Bénin.

[21] Mama, D., Deluchat, V., Bowen, J., Chouti, W., Yao, B., Gnon, B. and Baudu, M. (2011) Characterization of a Lagoon 
System in Tropical Area: Case of Nokoue Lake (Benin). European Journal of Scientific Research, 56, 516-528.

[22] Goussanou, A. (2012) Diversity of Phytoplankton of Nokoue Lake. MSc Thesis, University of Abomey-Calavi, Cotonou.

[23] Viljoen, A., Cyrus, D.P. and Wepener, V. (2001) Comparison of the Density and Species Composition of Aquatic Invertebrates Found between the Roots of Eichhornia crassipes Plants from Two Coastal Lakes in Northern KwaZulu-Natal. African Journal of Aquatic Sciences, 26, 57-65. http://dx.doi.org/10.2989/16085910109503725

[24] Alhou, B. (2007) Impact of Discharges of Niamey (Niger) on the Water Quality of the River Niger. PhD Thesis, University of Namur, Namur.

[25] Nickles, M. (1950) Shellfish Marine Molluscs of the Western Coast of Africa. West Africans Manuals, II/Ed., Paris.

[26] Villiers, A. (1952) Hemiptera (Bugs and Cicadas) of black Africa. Initiations Africaines IX, French Institute of black Africa, Dakar.

[27] Hayward, P. (1980) Seaside Guide: North Sea, Channel, Atlantic, and Mediterranean. Delachaux Niestlé var.pag.

[28] Durand, J.R. and Leveque, C. (1981) Aquatic Flora and Fauna of Sudanese and Sahelian Africa. ORSTOM, Paris.

[29] McCafferty, P. (1981) Aquatic Entomology. The Fisherman's and Ecologists' Illustrated Guide to Insects and Their Relatives. Jones and Bartlett Publishers, Boston and London.

[30] Food and Agriculture Organization (1992) Field Guide of Commercial Marine Resources of the Gulf of Guinea. FAO, Rome.

[31] Moisan, J. (2010) Identification Guide to Key Freshwater Benthic Macroinvertebrates Quebec_-Monitoring Voluntary Courses Shallow Water. Direction of Environment State Monitoring, Ministry of Sustainable Development, Environment and Parks, Quebec.

[32] Ministère du Développement Durable, de l’Environnement, de la Faune et des Parcs MDDEFP (2013) Guide de surveillance biologique basée sur les macroinvertébrés benthiques d'eau douce du Québec_Cours d'eau peu profonds à substrat grossier. Direction du suivi de l'état de l'environnement.

[33] Pielou, E.C. (1975) Ecological Diversity. Wiley \& Sons, New York.

[34] Simpson, E.H. (1949) Measurement of Diversity. Nature, 163, 688. http://dx.doi.org/10.1038/163688a0

[35] Masese, F.O., Raburu, P.O. and Muchiri, M. (2009) A Preliminary Benthic Macroinvertebrate Index of Biotic Integrity B-IBI for Monitoring the Moiben River, Lake Victoria Basin, Kenya. African Journal of Aquatic Science, 34, 1-14. http://dx.doi.org/10.2989/AJAS.2009.34.1.1.726

[36] Fishar, M.R., Thorne, R. and Williams, P.W. (2006) Physical-Chemical Conditions and Macroinvertebrate Fauna in the River Nile from Aswan to Cairo. African Journal of Aquatic Science, 31, 247-259. http://dx.doi.org/10.2989/16085910609503894

[37] Abdel-Hamid, M.I., Abdel-Aal, E.I. and Azzab, Y.A. (2014) Spatial Quality Improvement of a Toxic Industrial Effluent, Based on Physico-Chemistry, Algal Community Changes and Algal Bioassay. African Journal of Aquatic Science, 39, 1-16. http://dx.doi.org/10.2989/16085914.2013.870524

[38] Mama, D. (2010) Méthodologie et résultats du diagnostic de l'eutrophisation du lac Nokoué Bénin. Thèse de doctorat, Université de Limoges, Limoges.

[39] Dovonou, F., Aina, M., Boukari, M. and Alassane, A. (2011) Physical Chemical and Bacteriological Pollution of an Aquatic Ecosystem and Its Eco-Toxicological Risk: Case of Nokoue Lake South Benin. International Journal of Biological and Chemical Sciences, 5, 1590-1602.

[40] Hyangya, B. (2012) Essai d’évaluation de l’influence des activités anthropiques sur la physico-chimie, la composition et l'abondance du plancton et des macroinvertébrés du littoral du lac Tanganyika Cas des zones littorales le long de Bujumbura Burundi et Uvira RD-Congo au nord du lac. Mémoire de Master, Université du Burundi, Burundi.

[41] Dèdjiho, C.A., Mama, D., Tomètin, L., Nougbodé, I., Chouti, W., Sohounhloué, C.K.D. and Boukari, M. (2013) Physical and Chemical Quality Assessment of Some Wastewater Tributaries of Ahémé Lake in Benin. Journal of Applied Biosciences, 70, 5608-5616. http://dx.doi.org/10.4314/jab.v70i1.98763

[42] Uwadiae, R.E. (2014) Environmental Characteristics and Community Structure of Benthic Macroinvertebrate of Epe Lagoon, Nigeria. International Journal of Environmental Sciences, 3, 36-44.

[43] Zabbey, N. and Hart, A.I. (2014) Spatial Variability of Macrozoobenthic Diversity on Tidal Flats of the Niger Delta, Nigeria: The Role of Substratum. African Journal of Aquatic Science, 39, 67-76. http://dx.doi.org/10.2989/16085914.2013.869657

[44] Zabbey, N. (2012) Spatial and Temporal Variability in Interstitial Water Quality of Soft-Bottom Flats at Bodo Creek, Eastern Lower Niger Delta, Nigeria. Tropical Freshwater Biology, 21, 83-103.

[45] Edia, O.E., Bony, K.Y., Konan, K.F., Ouattara, A. and Gourène, G. (2013) Distribution of Aquatic Insects among Four Costal River Habitats Côte d'Ivoire, West-Africa. Bulletin of Environment, Pharmacology and Life Sciences, 2, 68-77. 
[46] Imoobe, T. (2008) Variation in Benthic Macroinvertebrate Assemblages in Ologe Lagoon, Nigeria. African Journal of Aquatic Science, 33, 45-50. http://dx.doi.org/10.2989/AJAS.2007.33.1.5.389

[47] Kouadio, K.N., Diomande, D., Ouattara, A., Kone, J.M. and Gourene, G. (2008) Taxonomic Diversity and Structure of Benthic Macroinvertebrates in Aby Lagoon Ivory Coast, West Africa. Pakistan Journal of Biological Sciences, 11, 2224-2230. http://dx.doi.org/10.3923/pjbs.2008.2224.2230

[48] Verniers, G. and Descy, J.-P. (2013) Rivière: Le retour à la continuité écologique. Vidéogramme, FUNDP-URBO, Namur.

[49] Leigh, C. and Sheldon, F. (2009) Hydrological Connectivity Drives Patterns of Macroinvertebrate Biodiversity in Floodplain Rivers of the Australian Wet/Dry Tropics. Freshwater Biology, 54, 549-571. http://dx.doi.org/10.1111/j.1365-2427.2008.02130.x

[50] Paillex, A., Castella, E. and Carron, G. (2007) Aquatic Macroinvertebrate Response along a Gradient of Lateral Connectivity in River Floodplain Channels. Journal of the North American Benthological Society, 26, 779-796. http://dx.doi.org/10.1899/06-12.1

[51] Zilli, F.L. and Marchese, M.R. (2011) Patterns in Macroinvertebrate Assemblages at Different Spatial Scales. Implications of Hydrological Connectivity in a Large Flood Plain River. Hydrobiologia, 663, 245-257. http://dx.doi.org/10.1007/s10750-010-0576-1

[52] Odountan, H. and Abou, Y. (2015) Can macroinvertebrate Assemblage Changes Be Used as Biological Indicator of Water Quality of the Nokoue Lake (Benin)? Journal of Environmental Protection, 6, 1402-1416. http://dx.doi.org/10.4236/jep.2015.612122 